\title{
Resilience measurement of Padang city's infrastructures toward multi-hazard
}

\author{
Giani Ananda ${ }^{1, *}$, Taufika Ophiyandri ${ }^{1}$, and Edi Hasymi ${ }^{2}$ \\ ${ }^{1}$ Department of Civil Engineering, University of Andalas, Limau Manis, Padang, 25163, Indonesia \\ ${ }^{2}$ Padang City's Regional Board for Disaster Management, Pasar Ambacang, Padang, 25152, Indonesia
}

\begin{abstract}
The complexity of geographical conditions and regional morphology of Padang City have caused it to be at high risk of multi-hazard. Padang City is located near the meeting point of the IndoAustralian Plate and the Eurasian Plate, and also on the Sumatra Fault line (Semangko Fault). Therefore, strong infrastructures are needed in order to minimize the impact of the risk of multi-hazard. This study is conducted to measure the resilience of Padang City's infrastructures toward multi-hazard and provide recommendations to improve the resilience of Padang City's infrastructures toward Multi-hazard. This study was conducted with qualitative methods and presented quantitatively in the form of diagrams. The measurement is carried out based on the concept of city toughness measurements made by UNISDR known as the "Scorecard". This study only focuses on essential 8 about "Increase Infrastructure Resilience" and essential 10 about "Expedite Recovery and Build Back Better". From this study, it can be concluded that the resilience of Padang City infrastructures is still relatively low so several recommendations that are expected will increase the resilience of Padang City's infrastructures are proposed, that are; in-depth assessment, data collection and supervision monitoring of infrastructures, important assets, and protective infrastructure.
\end{abstract}

\section{Introduction}

The complexity condition of its geographical and regional morphology have caused Padang City to be exposed to multi-hazard. Besides being located near the meeting point of Indo-Australian Plate and the Eurasian Plate, Padang City is also located on the Sumatera Fault Line and near to Mentawai Fault Point[1]. One of the potential disaster that has caused physical damage and victims is a quietly huge earthquake disaster that occurred on September $30^{\text {th }}, 2009$. Where the final data shows the number of victims died in West Sumatera is 1.195 people. The other victims that seriously injured are 619 people and 1.179 minor injuries based on data. While the material loss data mentioned 114.797 resident houses were severely damaged, 67.198 were moderately damaged, and 67.828 were lightly damage. For public facilities damage, there was 2.163 of educational room, 51 unit of medical facilities, 1.001 of worship facilities, 21 of the bridge, 178 unit of roads, and 130 irrigation facilities were severely damaged. Total estimation of loss and damage was Rp. 15,41 Triliyun. [2,3].

The purpose and objective of this research are to measure the resilience of Padang City's infrastructure towards multi-hazard, and also to propose the recommendations that can increase the resilience of infrastructure so it can be useful to all parties.

\subsection{Multi-Hazard in Padang City}

\subsubsection{Padang City}

Padang City is located on the west coast of Sumatera Island and between $0^{\circ} 44^{\prime} 00^{\prime \prime}-1^{\circ} 08^{\prime} 35^{\prime \prime}$ South Latitude and $100^{\circ} 05^{\prime} 05^{\prime \prime}-100^{\circ} 34^{\prime} 09^{\prime \prime}$ East Longitude. The area of Padang City region according to Peraturan Daerah no. 10,2005 is $1.414,96 \mathrm{Km}^{2}$ [4].

According to the regional geology, Padang City is the combination of volcanic field forms in the east side, alluvium field forms in the middle part and marine field in the west part since it has several rivers that have permanent flows throughout the year. It has a high rain intensity and ocean tide has increased the danger of flood to occur. Padang City region is located in the west coast of Sumatera Island, directly connected with the Hindia Ocean so it has huge-waves that has potential for extreme wave and abrasion to occur. The west region is a dynamic tectonic area. It is caused by the subduction/interaction of 2 plates, that are Indo-Australia and Eurasia plate. With the process, the Padang region has become vulnerable to earthquake disaster that has the potential to be followed by a tsunami. The potential source of earthquake in Padang region was found in 3

\footnotetext{
*orresponding author: gianiananda@gmail.com
} 
zones, they are subduction zone (both inter and intraplate), Mentawai Fault Zone and Sumatera Fault Zone[5].

\subsubsection{Multi-Hazard}

Multi-hazard is a combination of several disaster hazards. In the history of disasters in Padang City there is 6 (six) kind of disaster that has occurred as shown in the following table[6] :

Table 1. Records of Padang City Disaster 1815-2012

\begin{tabular}{|c|c|c|c|c|c|c|}
\hline \multirow{2}{*}{ 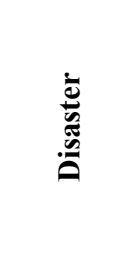 } & \multirow{2}{*}{ 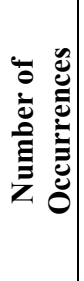 } & \multirow[b]{2}{*}{ 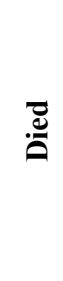 } & \multirow{2}{*}{ 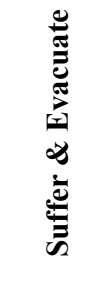 } & \multicolumn{3}{|c|}{ Damaged Houses } \\
\hline & & & & $\begin{array}{l}\frac{2}{d} \\
\frac{0}{0} \\
\ddot{D}\end{array}$ & 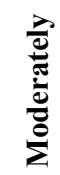 & 离 \\
\hline Flood & 37 & 15 & 22276 & 63 & 56 & 299 \\
\hline $\begin{array}{l}\text { Extreme } \\
\text { waves } \\
\text { and } \\
\text { abrasion }\end{array}$ & 9 & 1 & 4020 & 72 & 0 & 4 \\
\hline $\begin{array}{l}\text { Earth- } \\
\text { quake }\end{array}$ & 8 & 390 & 0 & 37587 & 0 & 78891 \\
\hline $\begin{array}{l}\text { High- } \\
\text { velocity } \\
\text { wind }\end{array}$ & 17 & 1 & 140 & 88 & 33 & 104 \\
\hline Dryness & 1 & 0 & 0 & 0 & 0 & 0 \\
\hline $\begin{array}{l}\text { Land- } \\
\text { slide }\end{array}$ & 12 & 35 & 3040 & 45 & 3 & 105 \\
\hline Total & 84 & 442 & 29476 & 37855 & 92 & 17196 \\
\hline
\end{tabular}

Hence, the government of Padang City in this case carried out by the Regional Board for Disaster Management (BPBD) of Padang City has conducted a study of disasters. According to the study, there are 4 kinds of hazard that becomes a priority. Followings are the disaster priority by BPBD of Padang City [7]:

Table 2. Disaster Priority of Padang City

\begin{tabular}{|l|c|c|c|}
\hline \multicolumn{1}{|c|}{$\begin{array}{c}\text { Kind of } \\
\text { Hazard }\end{array}$} & $\begin{array}{c}\text { Danger } \\
\text { Level }\end{array}$ & $\begin{array}{c}\text { Tendency } \\
\text { of Events }\end{array}$ & Priority \\
\hline Flood & High & Increasing & Priority 1 \\
\hline Tsunami & High & Permanent & Priority 2 \\
\hline Earthquake & Moderate & Increasing & Priority 2 \\
\hline $\begin{array}{l}\text { Extreme } \\
\text { Wave and } \\
\text { Abrasion }\end{array}$ & High & Decreasing & Priority 3 \\
\hline
\end{tabular}

From Table 2 can be known, priority 1 of disaster in Padang City is flooding, followed by earthquake and tsunami, and huge wave and abrasion took the last priority. Therefore, it is necessary to conduct research about infrastructure resilience towards multi-hazard, especially in infrastructure case.

\subsection{Infrastructure Resilience}

\subsubsection{Resilience}

Resilience is interpreted as an effort to anticipate, plan, and reduce the risk of disaster to effectively protect people, society and country, livelihood, health, cultural heritage, social assets, economic, and ecosystem. The idea of 'build back', 'better', and 'build back better' are often used in the context of resilience [8,9]. The objective of actualizing resilience is to make sure that the shock and pressure do not lead to a long-term decreasing in developmental development [10].

A resilience city has the ability of system, community or society who are facing the disaster, to survive, absorb, accommodate and recover from the disaster events in an effective time period and efficient effort, including the preservation and restoration of building and other important facilities, which is in general, resilience is the ability to reflect back a shock $[11,12]$.

\subsubsection{Infrastructure}

Infrastructure is a physical component of facilities which requires a large investment. Providing a general service or solving the problem is a government responsibility. Being planned, designed, constructed, and operated with government assistance [13]. Infrastructure is also defined as the physical facilities that are being developed and needed by the public agents for governmental functions in water supply, electrical power, waste disposal, transportation, and other services to facilitate the economic and social objectives [14].

\subsubsection{Scorecard}

The measurement of the city's resilience first time introduced by UNISDR called 'scorecard'. A scorecard is the ability of a system, community or society that is exposed to hazards to survive, absorb, accommodate, adapt, change and recover from the effect of the hazard in time and efficient, including the preservation and structural recovery and the basic function Essential through the risk management [15].

This scorecard is made with the intention of [16] :

1. To help the country and regional government in monitoring and review the progress and challenges in Sendai Frameworks implementation.

2. To increase the possibility of the development of local disaster risk-reducing strategy (resilience action plan)

The benefit of scorecard-use is to support cities in : 
1. Establish the initial measurement of the resilience level towards potential disaster;

2. Increase the awareness and understanding about resilience challenge;

3. Activate the dialog and consensus between the city's stakeholders that may not well-organized;

4. Activate the discussion about the priority to invest and action, according to the mutual understanding about the current situation;

5. At the end lead to action and project that can be implemented and give the greater resilience for the city from time to time.

Followings are the scorecard, 10 essential of disaster resilience measurement according to the UNISDR concept:

Est.1. Availability of disaster resilience organization.

Est.2. Identify, understand, and use the risk scenario this time and in the future.

Est.3. Strengthen the financial capacity to actualize the resilience.

Est.4. Strive for resilience city development and planning.

Est.5. Protect the natural buffer to increase the protective function of the ecosystem.

Est.6. Strengthen the organizational capacity for resilience.

Est.7. Understand and strengthen the society capability to actualize the resilience.

Est.8. Increase infrastructure resilience.

Est.9. Ensure effective preparedness and disaster response.

Est.10.Accelerate the recovery and build back better.

This study is focused on the infrastructure that is in essential 8 and 10 that related to infrastructure.

\section{Research Methodology}

The research methodology used in this research is interview technique. The question list for the interview is arranged according to the UNISDR's scorecard of 10 basic steps of city resilience that relate to infrastructure, that is LM8 and LM10. In the scorecard there is a condition with the worst-case condition, in this case, for Padang City, the scenario was made according to Contingencies Plan Document of Padang City. The disaster is limited to Flood, Tsunami and Earthquake, and Flash Flood because the contingencies documents are available only for those disasters.

The question of those questions will be in the form of number from scale $0-5$ followed by the reason of the given score along with the question improvement in order to lead to the policies that has been made as the response to the situation that has been conceived in the questions to result to the recommendations that considered as necessary to increase the resilience of Padang City towards multi-hazards.

The interviewees of this study are 8 relevant agencies in Padang City as follows :

1. Regional Board for Disaster Management of Padang City (BPBD Kota Padang)
2. Board of Rivers Area of Sumatera V (BWS V)

3. Public Health Board of Padang City (Dinas Kesehatan)

4. Communication and Information Board of Padang City (Dinas Kominfo)

5. State Electricity Company of Sumatera Barat Area (PLN Wilayah Sumatera Barat)

6. Education Board of Padang City (Dinas Pendidikan)

7. Prison Class IIA of Padang City

8. Local Water-supply Company (PDAM Kota Padang)

Resilience measurement range in 4 value, as follows : $0,00-1,25$ : Very not resilience

$1,26-2,50:$ Not resilience

2,51-3,75: Resilience

$3,76-5,00$ : Very resilience

The interview data will be analyzed by using content analysis methods. First, the interview data will be recorded using a digital recorder. After that, the interview transcript will be made and the taken attribute will be given a code according to the research objectives.

\section{Results and Discussion}

\subsection{Resilience Measurement of Padang City's Infrastructure towards multi-hazards}

In this research, scorecard and contingencies plan document of Padang City is used as the basis of the measurement. Whereas the scorecard essential 8, subject/issue that can be measured in Padang City is :

1. Protective Infrastructure

2. Health care

3. Communication

4. Energy-Electricity

5. Education

6. Prison

7. Water sanitation

And for the Essential 10 about recovery.

For the worst scenario in earthquake and tsunami disaster happen in the morning in the busy hours at 10 WIB, begins with earthquake with the magnitude of 8,9 $\mathrm{SR}$, with depth of $30 \mathrm{~km}$, the first wave reached the coast in 20 minutes with height of 8-12 m above the sea level, in 3-4 hours after earthquake and landings $2-3 \mathrm{~km}$ in lowland. [17].

For flood disaster in Padang City, the worst scenario happen at $02.00 \mathrm{WIB}$ at night when people are asleep, with the average rain intensity $20-50 \mathrm{~mm}$ /hours that fall continuously causing $70-300 \mathrm{~cm}$ flood height followed by ocean tides. [18].

While for the flash flood worst scenario relatively same with the flood, happens at 2 am at night when the people in the Kuraji river flow area are asleep, the flow velocity is $10-30 \mathrm{~km} /$ hours with the height of flood is 70 $300 \mathrm{~cm}$ above the river surface level [19].

From those worst scenario, the disaster exposed society is for tsunami and earthquake 54.733 people, flood 180.900 people and for flash flood 24.754 people, with a total population of Padang City is 914.968 people. 
According to the research, followings are the result and discussion of the subject/issue that is measured.

\subsubsection{Earthquake and Tsunami}

Earthquake and tsunami are an unity of hazard that has summarized in a contingency planning document. As mentioned before, hazard exposure for a tsunami is 54.733 people, while for earthquake, the exposure area is all of Padang City population but at a different level. Earthquake is a hazard that has happened and caused a quite big loss in Padang City. Therefore, Padang City should have prepared to deal with it. According to the survey that was done on the subject/issue, the result for resilience measurement at essential 8 of earthquake hazard is obtained as shown in Fig. 1:

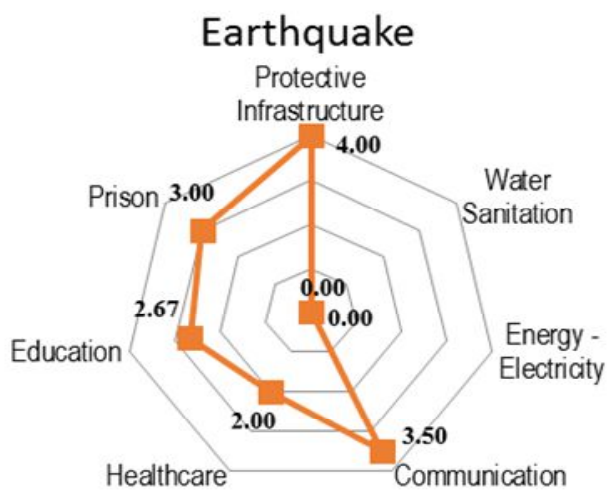

Fig. 1. Chart of Earthquake at Essential 8

From Fig. 1 above, it can be seen that the resilience measurement that has the highest index is at the protective infrastructure. Furthermore, the result of resilience measurement at tsunami hazard is shown in Fig. 2 as follows :

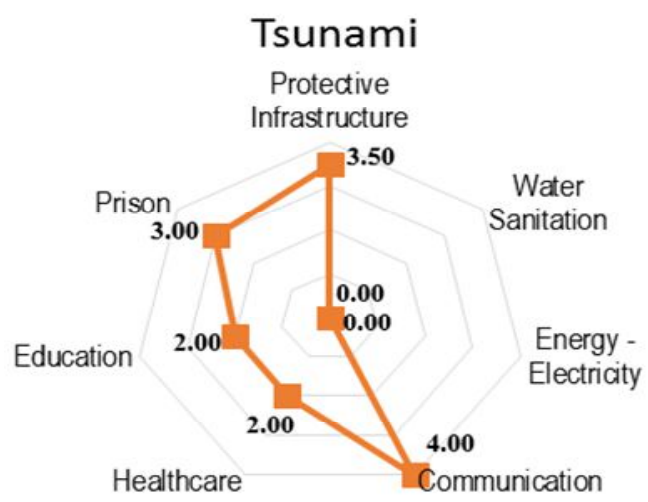

Fig. 2. Chart of Tsunami at Essential 8

In Fig. 2, the highest resilience level is communication.

\subsubsection{Flash Flood}

Flash flood is the hazard with the smallest exposure among the others. The measurement result of resilience towards flash flood is shown in Fig. 3 :

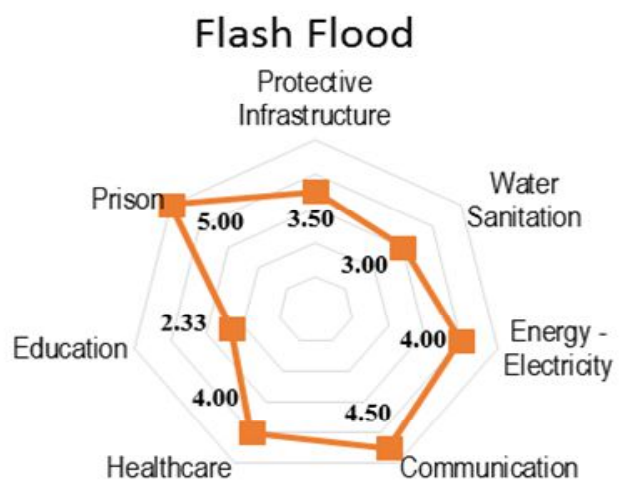

Fig. 3. Chart of Flash Flood at Essential 8

Fig. 3 shows that prison is the toughest subject/issue. It's because the building location is not exposed to flash flood hazard.

\subsubsection{Flood}

The resilience measurement result in flood hazard according to essential 8 is shown in Fig. 4 :

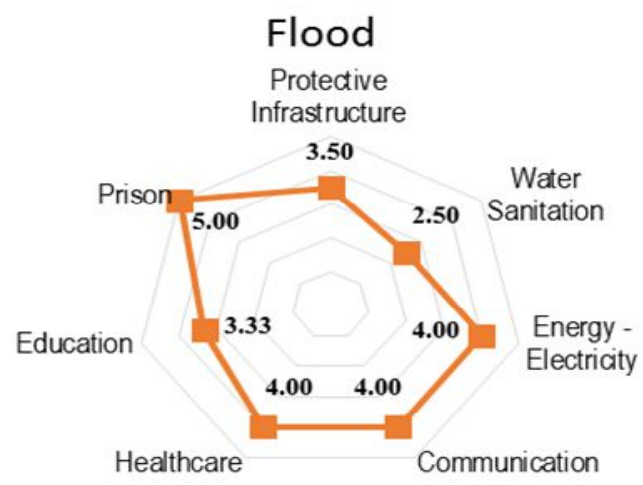

Fig. 4. Chart of Flood at Essential 8

Just like in flash flood hazard, prison is subject/issue that located in the flood-hazard unexposed location so that have the highest resilience level.

\subsubsection{Multi-Hazard}

According to the infrastructures resilience measurement in Padang City towards several hazards that have been mentioned before, they are earthquake and tsunami, flash flood, and flood, the result of infrastructures resilience measurement in Padang City towards multi-hazard based on essential 8 is shown in Fig. 5 as follows : 


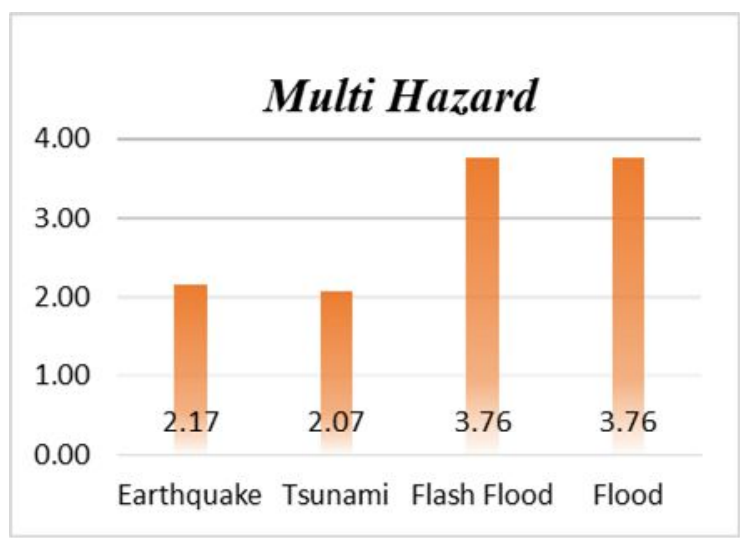

Fig. 5. Chart of Multi-hazard at Essential 8

Fig. 5 shows the index value of each hazard of Padang City's infrastructure resilience towards multihazard if arranged descendingly is as follows :

1. Resilience towards Flash Flood $(3,76)$ : Very Resilience

2. Resilience towards Flood $(3,76)$ : Very Resilience

3. Resilience towards Earthquake $(2,17)$ : Not Resilience

4. Resilience towards Tsunami (2,07): Not Resilience

\subsubsection{Expedite Recovery and Build Back Better}

Measurement of Expedite Recovery and Build Back Better is based on Essential 10 which is conducted to know how much index that has been resulted in case of recovery time preparation that has been done. Following is the result of Essential 10 measurement as shown in Fig. 6 :

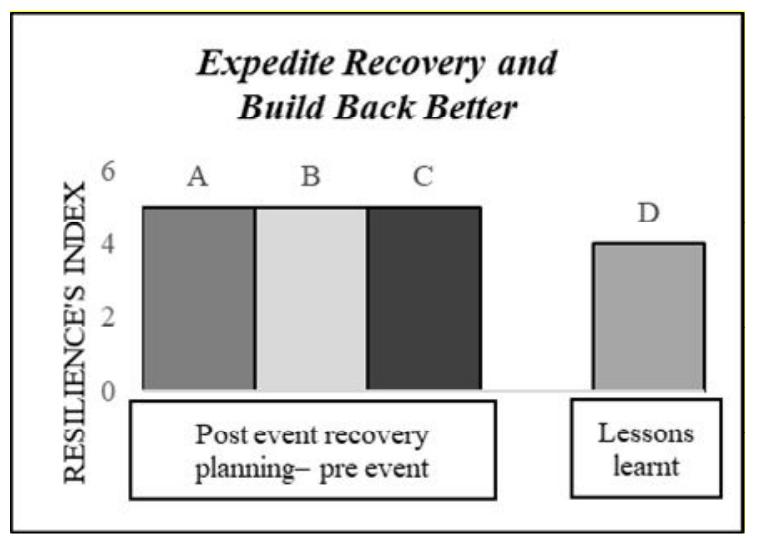

Fig. 6. Expedite Recovery and Build Back Better

Adjective :

A: Planning for post-event recovery and economic reboot

B: Extent to which there has been stakeholder consultation around the 'event recovery and reboot' plans

C: Shadow financial arrangements for processing incoming aid and disbursing funds

D: Learning loops

According to the result and discussion, the index of both essential can be obtained as shown in Fig. 7 below :

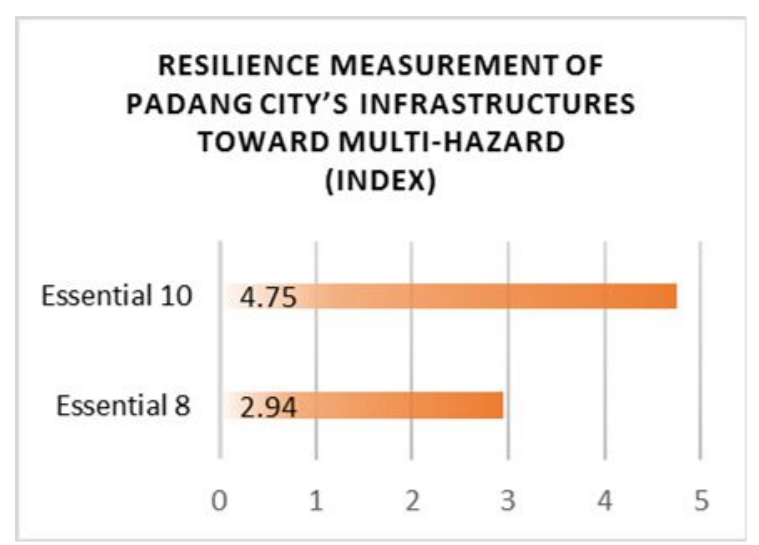

Fig. 7. Resilience Measurement Of Padang City's Infrastructures Toward Multi-Hazard (index) Graph

Therefore, based on Fig. 7 can be concluded that :

1. Padang City's Infrastructure is resilience towards 4 multi-hazard that is an earthquake, tsunami, flash flood, and flood.

2. Recovery and build back better planning in Padang City has a very resilience index so that is expected to be done in line with expectation.

\subsection{Recommendation Proposed to Increase the Infrastructure Resilience of Padang City towards Multi-Hazard}

According to the result of Infrastructure Resilience Measurement of Padang City towards Multi-Hazard, it can be proposed some recommendation to increase it, that is :

1. In-depth assessments of the infrastructure problems in Padang City.

2. Massively data collection of important city assets and protective infrastructures.

3. The existing data is backed up periodically, both in the form of hard copy and soft copy, especially at the place that is not exposed to disasters.

4. Increasement of supervision in routine monitoring and evaluation towards Padang City's important assets.

5. Coordination between related agency in order to synchronize the existing data and result in a valid and well-known disaster prevention document.

\section{Conclusion}

From this research, it can be concluded that after the measurement of infrastructure resilience of Padang City towards multi-hazard according to Scorecard Concept and Contingencies Planning Document of Padang City it can be obtained the index result 2.94 for infrastructures and 4,75 for recovery. It shows that the infrastructures of Padang City are valued resilience in facing the multihazard. To increase it, several recommendations can be proposed, that is an in-depth assessment of infrastructure problems, massively collecting data of important assets of Padang City including protective infrastructure. And then the existing data is backed up periodically. From the existing data, the supervision in Padang City's assets 
monitoring and evaluation can be increased. The most important thing of all is the coordination of all related agencies in order to synchronize the data and result in a valid disaster prevention plan document of Padang City.

\section{References}

1. B. Mustafa, The analysis of Nias and West Sumatera Earthquake and the Similarity which does not cause a tsunami. J. Ilmu Fis. | Univ. Andalas. 2, no. 1, pp. 44-50, (2010).

2. T. Ophiyandri, B. Istijono, D. Chairisna, and A. Tadzkia, The satisfaction level of societies towards Housings Rehabilitation and Reconstruction Program Pasca Earthquake September 30th, 2009 in West Sumatera Province. no. September 2009, (2011).

3. Z. Alhadi, Readiness of Route and Location Public Evacuation towards Earthquake and Tsunami Disaster Risks in Padang City (Disaster Management Disaster). Humanus, 13, no. 1, p. 35, (2014).

4. P. K. Padang, Spatial Plan of Padang City Area 2010 - 2030, (2012).

5. Deputy for Prevention and Preparedness for the National Board for Disaster Management, Disaster Risk Assessment of Padang City, West Sumatera 2014 - 2018. (2013).

6. BNPB, "Data \& Information of Disasters in Indonesia (DIBI) 1815-2018.”.

7. Deputy for Prevention and Preparedness for the National Board for Disaster Management, Disasters Prevention Planning Documents of Padang City 2014 - 2018. (2018).
8. T. D. O. Rourke, Critical Infrastructure Security, and Resilience, (2019).

9. Siemens, ARUP, and RPA, Toolkit for Resilient Cities Infrastructure, Technology, and Urban Planning, SIEMENS Toolkit For Resilient Cities, p. 66, (2013).

10. T. Mitchell and K. Harris, Resilience: A risk management approach, ODI Background Note. Overseas Development Institute, London, (2012).

11. R. Papa, A. Galderisi, M. C. . Vigo Majello, and E. Saretta, Smart and Resilient Cities. A Systemic Approach for Developing, TeMA J. L. Use, Mobil. Environ., 1, no. Cities, Energy and Climate Change (1), (2015).

12. Mercy Corps Indonesia, Guidelines to City Resilience Strategy (CRS) Making, (2016).

13. S. Maryati, Infrastructure System, Regional and City Infrastructure, pp. 1-27, (2014).

14. R. B. Prasetyo and D. M. Firdaus, The effect of Infrastructure to the Regional Economic Growth in Indonesia, J. Ekon. dan Kebijak. Pembang., 2, pp. 222-236, (2009).

15. IFRC, Sendai Framework for DRR, no. March, p. 25, (2015).

16. 1UNISDR, Disaster Resilience Scorecard for Cities Detailed level assessment, p. 118, (2017).

17. BPBD of Padang City, Contingencies Planning Document for Tsunami Disaster in Padang City, (2017).

18. BPBD of Padang City, Contingencies Planning Document for Flood Disaster in Padang City, (2017).

19. BPBD of Padang City, Contingencies Planning Document for Flash Flood in Padang City, (2017). 